\title{
THE INFLUENCE OF FINANCIAL KNOWLEDGE ON THE EFFICIENCY OF FISCAL POLICY. THE CASE OF INCOME INEQUALITY IN LITHUANIA
}

\author{
Prof. Dr. Gediminas Dubauskas \\ General Jonas Žemaitis Military Academy of Lithuania
}

\begin{abstract}
The improvement of public finances is an important issue for any country's development. This content is changing public sector and sustainability of citizens environment; therefore, much attention is paid to the widespread improvement of financial research. In addition, activities may be organized in connection with applicable higher education programs. On the other hand, education in the field of financial management in different countries is interpreted differently. It has become increasingly important that such a discussion does not directly contribute to the overall development of financial education in recent years. One of the possible ways to handle personal finances in various economic conditions may be to change the attitude of students to the knowledge provided by universities. Young people should be supported by financial education included in their study programs. Proper management of these programs helps to improve the educational process and their economic situation. Ultimately, the best way to determine the tax paid by individuals and legal entities could be called their rate of tax burden. However, an ordinary citizen who lives only from the income related to labor relations and has a higher tax burden may be a more important problem.
\end{abstract}

Another keyobjective of the paper is to disclose how citizens perceive taxation and public spending. The objective of the paper is to show the impact of the tax incidence in Lithuania during the last decade. Thus, we can consider almost doubled increase in the burden of direct taxes compared with the officially declared average tax burden of the country. Nonetheless, an additional tax burden includes hidden taxes related to payments from the individuals' total income. On the average, the tax burden for an ordinary worker can be about two-thirds of his/her gross annual income. The perception of the tax burden can lead every citizen of the country to be responsible for all the actions of public servants and budget planning processes. Raising government revenues is often difficult due to the use of the concept of fixed costs for public sector when a person directly pays additional payments for most public sector services. Thus, the confusion of terms is quite constant showing the need for literacy in public finance. In recent years, the accredited tax burden of Lithuania has been more than thirty per cent of the country's nominal gross domestic product. However, political leaders and experts suggest plans for increasing Lithuania's tax burden. Besides, there was a critical error concerning contributions to social insurance and compulsory health insurance funds. Fortunately, in 2018, the national budget included social payments in the budget revenues.

Keywords: public management, tax burden, taxation, budget, economic sustainability. 


\section{Introduction}

The purpose of the paper is to study the essence of tax burden and tax payments and their distinctiveness in Lithuania. A part of this paper is built on a systematic approach and is based on the application of methods of structural and comparative analysis, synthesis, induction, deduction and formalization as well as a complex of methods to estimate the value (in absolute terms) and the extent (in relative terms) of tax burden. The article revealed that the tax burden in modern Lithuania is relatively high and likely to cause shadow economy. The aggregated tax burden on Lithuania's working population as of the end of 2018 amounts to 56 per cent (see Figure 2).

Finance and public money management have a historical concept of the educational process and could be one of the key economic preparations in modern education. Financial knowledge is possible with a number of complex aspects, such as constant changes in the free market and the monetary policy of the European Union. Moreover, that knowledge is probably necessary for the university education. Financial education is relevant to every undergraduate program.

The purpose of this publication is to disclose public perception of the administrative and financial aspects of mismanagement of state revenues associated with the tax burden. The objectives of the paper are as follows: to consider the development of financial and public finance in modern scientific literature and to show the need for teaching students public finance and public expenditure management. One of the key tasks of the paper is to reveal how citizens perceive taxation, government spending, and fiscal policy. In addition, the article also tries to answer the questions about the financial and economic importance of financial education.

The research methods and methodological analysis used in the study were formal research and qualitative and quantitative research methods. The data were taken from the Lithuanian and EU financial institutions. Modification of full-time and part-time students and cadets was used for informal surveys. It is noteworthy that the data was collected from textbooks on public finance management, textbooks and teaching aids collected by the author over a long period of time.

The continuity and sustainability of public finances are currently sensitive topics in the discussion on economic policy. This could be due to the long-term pressure on the government spending caused by intrusive demographic changes in the developed countries. The paper analyzes some of the conceptualizations that were used to assess the tax incidence on the Lithuanian citizens. Hypothetical sustainability criteria are also considered. There is no consensus among economic experts on the theoretical standard for the continuity of public finances and, in particular, sustainability. Alternatively, each conceptualization to assess continuity and sustainability introduces its own personal, sometimes different, definitions. The paper examines the strengths and weaknesses of each approach. The availability of data and resources and other constraints for a particular case affect the relative quality of approaches in various situations. After the financial crisis of the first decade in the 
twenty-first century, public debts of many countries were on a sharp upward path due to the forced accumulation of various resources and savings aimed at the financial field and the entire economic system. The increase in obligations integrated with long-term entities, similar to the modification of the sociological layer, affects the symmetry among people in the workforce and the number of pensioners.

\section{Tax Incidence}

In economics, the tax incidence or tax burden is the effect of a particular tax on the distribution of economic wealth. Economists distinguish between legal entities that end up with a profit tax burden and those that are individually taxed. The tax burden measures the real economic weight of tax measured by the difference between real income before and after the introduction of tax. A taxable person was not required to pay the actual amount of tax before 2019; however, an employer paid an employee social insurance taxes. These amounts usually were not included in an individual's tax burden.

The aim of the article is to investigate the nature of tax burden and tax payment and their differences in Lithuania. The methodological part of the paper is built on a systematic approach and is based on the application of methods of structural and comparative analysis, synthesis, induction, deduction and formalization as well as a complex of methods to estimate the value (in absolute terms) and the extent (in relative terms) of tax burden. In the course of the study, it was revealed that the tax burden in modern Lithuania is relatively high and likely to cause shadow economy. Tax experts have long been theorizing about raising money for various ministries and functions of the government. Should taxes be levied only on income or as a means of social control and how? Should taxes be levied on citizens equally or should "solvency" be the main consideration? Where possible, the "benefit principle" should be followed. Moreover, if the government provides services to specific individuals only, should those who receive direct benefits pay for this service (Sitglitz, 2015)?

The theory of tax incidence provides a rich assortment of such insights. A basic lesson on tax incidences that the real and nominal tax burdens are not necessarily related means that taxes on capital are paid by workers, investment incentives are injurious to capitalists, taxation of foreigners simply represent indirect domestic taxation, and future generations may be supporting the current ones.

The study of tax incidence is very important because of its implications about the impacts on government policies. Much of current tax incidence literature address the settings of certainty, perfect information, and market clearing (Chengjian, 2015). Taxation has become a tool of monetary and fiscal management. Experts speak of "calibration" in economy that employment will be high and productivity will expand. The doubtless are those who look upon taxation as a means of redistributing wealth in the belief that some have too much income while others too little. The progressive income tax is an expression of this belief as are current discussions on a 
guaranteed annual income for all. So, in the view of the growing tax burden and the increasing use of taxes as a tool for social and fiscal control, let us further review the new theories and modern problems of taxation.

According to economists, payment of taxes results in the reduction of individuals' incomes (Abuselidze, 2012). They grow poorer, have to suspend the retirement, reduce spare time on the cost of increasing working hours, etc. In economics, the tax proportion or tax burden is the effect of a particular tax on the distribution of economic wealth. The tax burden measures the real economic weight of the tax measured by the difference between real income and utilities before and after the introduction of the tax. The purpose of the paper is to study the essence of tax burden and tax payments and their peculiarities in Lithuania.

Tax experts have long been theorizing about raising money for various ministries and functions of the government. Should taxes be levied only on income or as a means of social control (Komlos, 2019)? Should taxes be levied on citizens equally or should "solvency" be the main consideration? Where possible, the "benefit principle" should be followed. That is, if the government provides services to specific individuals, and not to all, should those who receive direct benefits pay for this service (Oto-Peralias, 2013)? The theory of tax incidence provides a rich assortment of such insights. The basic lesson of the tax incidences that the real and nominal tax burdens are not necessarily related means that taxes on capital are paid by workers, investment incentives are injurious to capitalists, taxation of foreigners simply represent indirect domestic taxation, and generations alive many decades in the future may be supporting those currently alive (Nuta, 2008).

The study of tax incidence is very important because of its implications about the impacts of government policies. Much of current tax incidence literature considers the settings of certainty, perfect information, and market clearing (Berggren, 2014). As more sophisticated models relax these assumptions, the theory of tax incidence is enriched and, with all probability, provides even more surprising and exciting economic insights. Taxation has become a tool of monetary and fiscal management.

The clarity of government spending, procurement, and budget policies are important issues for each country. As discussed in several countries of the European Union, financial education and literacy are essential for general civic education to improve the paradigm of financial knowledge and skills (De Haan, 2002). This is especially true for higher education institutions in connection with relevant higher education and research programs.

Government-induced inflation is a sustained annual increase in prices caused by the expansion of money supply to pay for government-supplied goods and services. Government authorities can simply print money to pay for costs of government-provided goods and services or take other measures to expand money supply (Davig, 2011). Inflation induced by the government's expansion of the monetary base reduces the purchasing power of money held by the public.

The reduction in the real value of money is the "inflation tax" that ultimately 
reduces command over resources in the private sector and transfers resources to the government use. The more money is created to finance government purchases, the greater the burden in terms of inflation and reduction in the purchasing power of the private sector. Inflationary government finance can be used only for short periods of time (Hymen, 2011). Eventually, individuals will develop techniques to avoid holding domestic money. They could use foreign currency for transactions or develop techniques to minimize the amount of money they hold. If it occurs, the government has to issue more and more money to meet its expenses and the inflation rate has to increase accordingly. The eventual result is hyperinflation, where inflationary expectations are constantly increasing. The efforts to unload money balances cause rapidly increasing inflation rates.

The ever higher inflation is also likely to cause declines in both saving and investment within a nation. Individuals try to acquire foreign currencies and export capital. It often leads to political instability and "austerity programs" that sharply reduce government spending and borrowing. In short, it is prudent for governments to avoid using inflation as a means of financing their expenditures.

\section{Tax Burden Assessment}

In economics, the tax proportion or tax burden is the effect of a particular tax on the distribution of economic wealth. The tax burden measures the real economic weight of the tax measured by the difference between real income or utilities before and after the introduction of tax (Bergh, 2011). The purpose of the paper is to study the essence of tax burden and average personal tax payments in Lithuania. The methodological unit of this paper is built on a systematic approach and is based on the application of methods of structural and comparative analysis, synthesis, induction, deduction and formalization as well as a complex of methods to estimate the value of the tax burden.

In the course of the study, it was revealed that the tax burden in modern Lithuania is relatively high in terms of money (see Figure 1). However, a more representative analysis of the tax burden is in the percentage scale from the gross average wage income (see Figure 2). Therefore, in the official sources the average country's tax burden as the National Budget to the Gross Domestic Product ratio is about 30 per cent (LSMP, 2019). However, the citizens living from the labourrelated income were levied with 55 per cent payments during the years 2008-2018 (see Figures 1,2). In addition, public servants are constantly trying to increase their taxes and bill almost all services that are expected to be free.

In terms of transparency, local government spending should be accessible to all taxpayers, including detailed components and, possibly, comments on the suitability of the use of an accurate tax. Unlike the legislation on the state budget, local authorities can be considered as a family that is not partially isolated from these observations about daily expenses, and their municipal expenses should be affordable. Government 
spending provides a theoretical exam to balance two key issues, increase the tax base, create new jobs and maintain the quality of life of the municipal community.

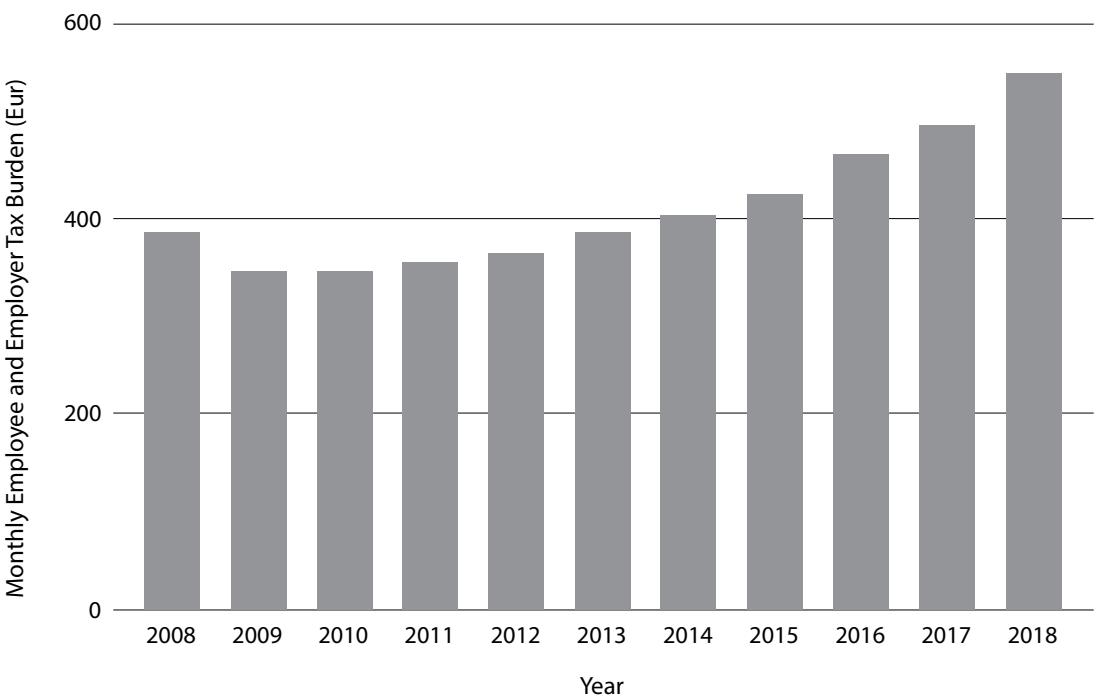

Figure 1. Lithuania's average monthly salary tax burden including social insurance tax paid by employer (Eur)

Source: Author's calculation

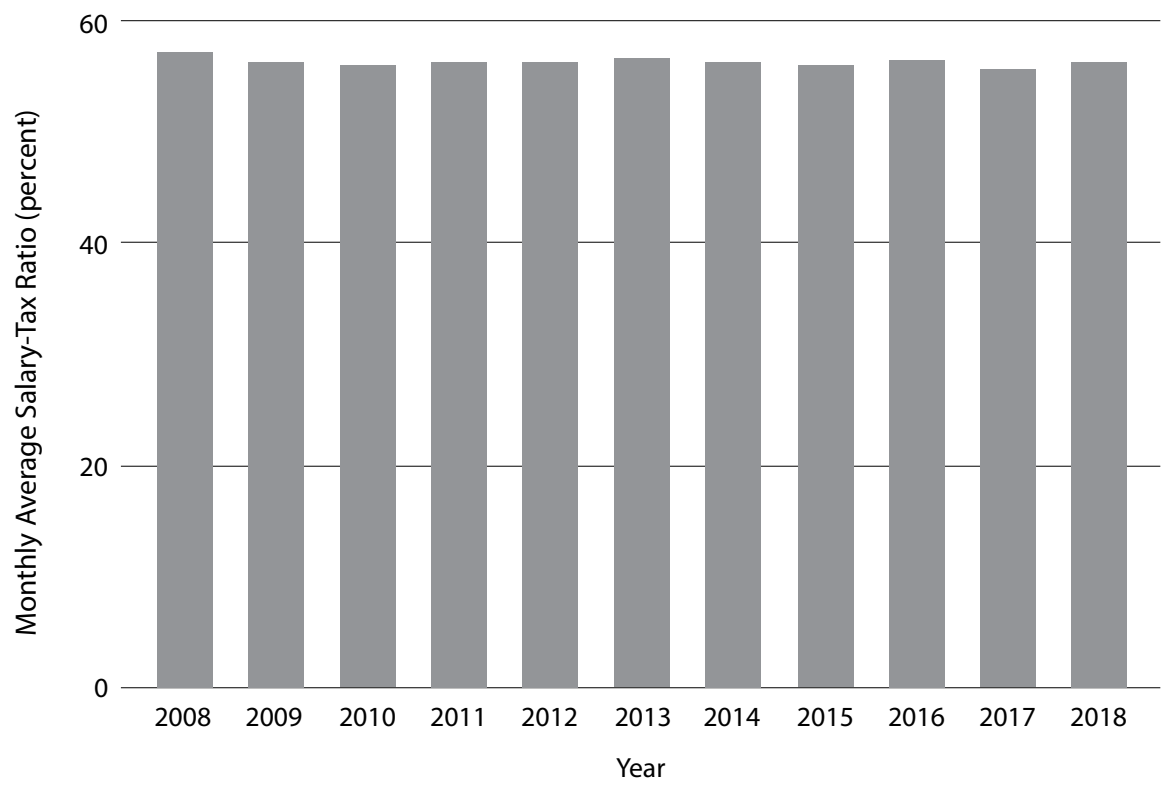

Figure 2. Lithuania's average monthly employee income-tax ratio including social insurance tax paid by employer (per cent)

Source: Author's calculation 


\section{Conclusions}

Improving public finances is an important issue for the development of any country. This content changes public sector and the sustainability of citizens' lives; therefore, much attention is being paid to the broad improvement of financial research. In addition, such educational activities may be organized in the context of the existing higher education programs. On the other hand, financial management education is interpreted differently in different countries. It is increasingly important that such a discussion does not directly contribute to the overall development of financial education in recent years. One possible way to manage personal finance in a variety of economic conditions may be to change students' attitude towards university knowledge. Proper management of these programs helps improve students' education process, their financial position and the understanding of taxation issues.

Another important purpose of the paper is to reveal how citizens perceive taxes and public spending, whereas the aim is to show the influence of taxes during the last decade. Thus, we can assume that direct tax burden has almost doubled from the officially declared average tax burden in the country. Nonetheless, additional tax burden includes hidden taxes on payments from all individuals' income. On average, an employee can have a tax burden of about two-thirds of the gross annual income. Officially, the tax burden can make every citizen responsible for all actions of public servants and budget planning processes. Thus, the confusion of concepts is quite persistent, which again demonstrates a need for literacy in public finance.

Lithuania's tax burden has accounted for more than thirty per cent of the country's nominal gross domestic product in recent years. However, political leaders and experts are proposing plans to increase Lithuania's tax burden. In addition, a critical mistake was made with regard to social security contributions and compulsory health insurance funds. At least last year's consolidated budget revenue included social contributions.

The sustainability of public finances is pressing an economic policy issue directly related to the tax burden and horizontal justice. The total direct tax burden for the Lithuanian citizens living on the employment-related income was more than 50 per cent last year. This is largely due to personal income tax with limited reductions, social security and compulsory health insurance contributions. At the same time, the total tax burden on the Lithuanian economy was about 30 per cent in 2018. Given the structure of the distribution of the tax burden between business and population and the increased burden on the latter, it is advisable to provide additional opportunities to reduce the tax burden on individuals at least by simplifying income tax relief. 


\section{References}

1. Abuselidze, G. (2012). The Influence of Optimal Tax Burden on Economic Activity and Production Capacity. Intellectual Economics, Vol. 6, pp. 493-503.

2. Barrios, S., \& Schaechter, A. (2008). The Quality of Public Finances and Economic Growth. European Economy - Economic Paper, 337. Tax Policy Review. Washington, IMF. 12.

3. Bergh, A. \& Henrekson, M. (2011). Government Size and Growth: a Survey and Interpretation of the Evidence. Journal of Economic Surveys, 25, $872-897$.

4. Berggren, N., Bjørnskov, C., \& Lipka, D. (2014). Legitimacy and the Cost of Government. IFN Working Paper No. 1045. Stockholm: Research Institute of Industrial Economics.

5. Davig, T., Leeper, E. M., Walker, T. B., (2011). Inflation and the Fiscal Limit. European Economic Review 55, 31-47.

6. De Haan, J., Sturm, J. E., and B. Volkerink (2002), 'How to Measure the Tax Burden on Labour', the paper presented at the CESifo Conference on Measuring the Tax Burden on Labour and Capital, Venice, July.

7. Dubauskas, G., (2013). Theories of Economics and Finance (Ekonomikos ir finansų teorijos), Vilnius, http://www.lka.lt/lt/moksline-veikla/leidiniai/leidiniu.../ ekonomika.html

8. Hymen, D. (2011). Public Finance. A Contemporary Application of Theory to Policy. South-Western Cengage Learning.

9. European Commission (2019). Taxation Trends in the European Union Data for the EU Member States, Iceland and Norway. 2019 ed. Luxembourg: Publications Office of the European Union. European Commission. Eurostat Database.

10. Komlos, J. (2019). Foundations of Real-World Economics. Routledge. Taylor \& Francis Group.

11. Li, Chengjian (2015). Tax Progressivity and Tax Incidence of the Rich and the Poor. Economics Letters Vol. 134.

12. Lietuvos stabilumo 2019 metu programa LSMP (2019). LR Finansų ministerija. https://ec.europa.eu/info/sites/info/files/2019-european-semester-stabilityprogramme-lithuania_lt.pdf

13. Nuta, A. C. (2008). The Incidence of Public Spending on Economic Growth. Euro Economica, 20, $65-68$.

14. Oto-Peralías, D., \& Romero-Ávila, D. (2013) Tracing the Link between Government Size and Growth: the Role of Public Sector Quality. Kyklos, 66, $229-255$.

15. Stiglitz, J. E., Atkinson, E. B., (2015). Lectures on Public Economics. M, Princeton University Press, p. 48-49. 


\title{
EKONOMINIO ŠVIETIMO FISKALINĖS POLITIKOS \\ EFEKTYVUMO TRŪKUMAI: PAJAMŲ \\ MOKESČIO ATVEJIS LIETUVOJE
}

\author{
Prof. dr. Gediminas Dubauskas \\ Generolo Jono Žemaičio Lietuvos karo akademija
}

\section{Santrauka}

Viešųų finansų gerinimas yra svarbus bet kurios šalies vystymosi klausimas. Šis turinys keičia viešajj sektorių ir piliečių gyvenimo tvarumą, todèl daug dẻmesio skiriama finansinių tyrimų tobulinimui. Be to, tokia ugdymo veikla gali būti organizuojama atsižvelgiant ị taikomas aukštojo mokslo programas. Kita vertus, išsilavinimas finansų valdymo srityje skirtingose šalyse aiškinamas skirtingai. Vis svarbiau, kad tokia diskusija tiesiogiai neprisidètų prie bendros finansinio švietimo raidos pastaraisiais metais. Vienas iš galimų būdų tvarkyti asmeninius finansus ịvairiomis ekonominèmis sąlygomis gali būti studentų požiūrio ị universitetų teikiamas žinias keitimas. Jaunimas turètų būti remiamas finansinio švietimo programomis, kurios yra ịtrauktos i jų programas. Tinkamas šių programų valdymas padeda pagerinti kariūnų ugdymo procesą ir pagerinti jų ekonominę padètį. Galų gale geriausias būdas nustatyti fizinių ir juridinių asmenų sumokètą mokestị galètų būti vadinamas jų mokesčių naštos dydžiu. Tačiau pilietis, gyvenantis tik iš su darbo santykiais susijusių pajamų ir turintis didesnę mokesčių naštą, gali būti svarbesnè problema. Kitas svarbus šio straipsnio tikslas yra atskleisti, kaip piliečiai suvokia mokesčius ir valstybès išlaidas. Be to, šios publikacijos tikslas - parodyti fizinių asmenų apmokestinimo raidą Lietuvoje per pastarajji dešimtmetį. Taigi galime laikyti, kad tiesioginių mokesčių našta padidejjo beveik dvigubai, palyginti su oficialiai deklaruota vidutine šalies mokesčiu našta. Nepaisant to, kad ị papildomą mokesčių naštą neįeina paslëpti mokesčiai, susiję su mokejjimais iš visų asmenų pajamų. Vidutiniškai paprasto darbuotojo mokesčiu našta gali sudaryti apie du trečdalius jo bendrujų metinių pajamų. Dėl mokesčiu naštos suvokimo kiekvienas šalies pilietis gali būti atsakingas už visus valstybės tarnautojų veiksmus ir biudžeto planavimo procesus. Didinti valdžios sektoriaus pajamas dažnai yra sunku dèl viešojo sektoriaus fiksuotų išlaidų sąvokos vartojimo, kai asmuo tiesiogiai moka papildomas išmokas už daugumą viešojo sektoriaus paslaugų. Taigi sąvokų painiava yra nuolatinè, tai dar kartą parodo raštingumo poreikị viešųjų finansų srityje. Pastaraisiais metais Lietuvos mokesčių našta sudare daugiau nei trisdešimt procentų nuo šalies nominaliojo bendrojo vidaus produkto. Tačiau politiniai lyderiai ir ekspertai siūlo planus, kaip padidinti Lietuvos mokesčių naštą. Be to, padaryta kritinè klaida, susijusi su įmokomis ị socialinị draudimą ir ị privalomojo sveikatos draudimo fondus. 
Bent jau ị praejusių metų konsoliduoto biudžeto pajamas buvo įtrauktos socialinès įmokos. Viešujų finansų tvarumas yra aktuali ekonominès politikos tema, tiesiogiai susijusi su mokestine našta bei horizontaliu teisingumu. Bendra tiesioginių mokesčių našta Lietuvos piliečiams, gyvenantiems iš pajamų, susijusių su darbo santykiais, 2018 metais sieke daugiau nei 50 procentų. Tai daugiausia lemia gyventojų pajamų mokestis su ribotomis mažinimo galimybėmis, ir socialinio draudimo ir privalomojo sveikatos draudimo įmokomis. Kai bendra mokesčių našta Lietuvos ekonomikai 2018 metais buvo apie 30 procentų. Atsižvelgiant ị pateiktą mokesčiu naštos paskirstymo tarp verslo ir gyventojų struktūrą ir atsižvelgiant ị padidejjusią pastarujų naštą, patariama suteikti papildomų galimybių sumažinti mokesčių naštą gyventojams, bent jau supaprastinant pajamų mokesčio mokejjimo lengvatas.

Raktiniai žodžiai: valstybès finansai, biudžetas, apmokestinimas, mokestinė našta, tvarumas

\section{AUTORIAUS LYDRAŠTIS}

Autoriaus vardas, pavardė: Gediminas Dubauskas

Mokslo laipsnis ir vardas: daktaras, profesorius

Darbo vieta ir pareigos: Generolo Jono Žemaičio Lietuvos karo akademija, Vadybos katedros profesorius

Autoriaus mokslinių interesų sritys: vadyba, finansai, ekonomika, edukologija.

Telefonas ir el. pašto adresas: (8 6) 727 9858; gediminas.dubauskas@lka.lt

\section{AUTHOR'S COVER LETTER}

Author's name and surname: Gediminas Dubauskas

Academic degree and name: Professor, Doctor

Workplace and position: Department of Management, General Jonas Žemaitis Military Academy of Lithuania

Author's research interests: management, finance, economics, education

Telephone and e-mail address: +37067279 858,

gediminas.dubauskas@lka.lt 